\title{
ANALISIS PENGARUH SUHU PENGERINGAN TERHADAP MUTU ORGANOLEPTIK PUNDANG SELUANG
}

\section{The Effect of Drying Temperature for Organoleptic Quality of Pundang Seluang}

\author{
Helmi Harris ${ }^{1)}$ dan Aan Agustiawan²) \\ ${ }^{1)}$ Ilmu Perikanan Fakultas Perikanan Universitas PGRI Palembang \\ 2) Alumni Fakultas Perikanan Universitas PGRI Palembang \\ Hp. Telp. (0711) 510043 fax. (0711) 514782 \\ Email: helmiharris76@yahoo.com
}

\begin{abstract}
Abstrak
Peningkatan Penelitian ini bertujuan untuk menentukan pengaruh suhu pengeringan menggunakan oven elektrik dan sinar matahari terhadap mutu organoleptik Pundang Seluang. Penelitian ini menggunakan Rancangan Acak Kelompok (RAK) dengan 4 (empat) taraf perlakuan, masing-masing perlakuan dilakukan 3 (tiga) kali ulangan. Perlakuan pada penelitian ini berupa penggunaan 4 (empat) variasi suhu yaitu : $\mathrm{T}_{0}$ (Pengeringan dengan sinar matahari sebagai Kontrol, $\mathrm{T}_{1}$ (Pengeringan menggunakan oven elektrik suhu $40{ }^{\circ} \mathrm{C}$ ), $\mathrm{T}_{2}$ (Pengeringan menggunakan oven elektrik suhu $45^{\circ} \mathrm{C}$ ), $\mathrm{T}_{3}$ (Pengeringan menggunakan oven elektrik suhu 50 ${ }^{0} \mathrm{C}$ ). Parameter yang diamati meliputi analisa mutu organoleptik. Hasil penelitian menunjukkan bahwa pengeringan menggunakan sinar matahari dengan suhu rata-rata $42{ }^{\circ} \mathrm{C}$ membutuhkan waktu pengeringan selama 14 jam, dengan rendemen $22.00 \%$, nilai organoleptik 7.88 Pengeringan dengan oven elektrik, perlakuan terbaik adalah pengeringan dengan suhu 45 0C (T2). Karakteristik mutu Pundang dari perlakuan $\mathrm{T}_{2}$ Pengeringan menggunakan oven elektrik suhu $45{ }^{\circ} \mathrm{C}$ dengan nilai organoleptik 7.90 , rendemen $22.33 \%$, waktu pengeringan 14.09 jam Pengeringan menggunakan sinar matahari menghasilkan pundang dengan penampakan lebih cerah dan tidak getas.
\end{abstract}

Kata Kunci: Mutu organoleptik, Pengeringan, Pundang Seluang, dan Variasi suhu

\begin{abstract}
This study aims to determine the effect of drying temperature using electric ovens and sunlight on organoleptic quality of Pundang Seluang. This study used a Randomized Block Design (RBD) with 4 (four) levels of treatment, each treatment performed 3 (three) replications. The treatment in this study is the use of 4 (four) temperature variations, namely: TO (Sun drying as a Control, T1 (Drying using an electric oven temperature of $40{ }^{\circ} \mathrm{C}$ ), T2 (Drying using an electric oven at $45{ }^{\circ} \mathrm{C}$ ), T3 (Drying using an oven electric temperature $50{ }^{\circ} \mathrm{C}$ ) The parameters observed included organoleptic quality analysis The results showed that drying using sunlight with an average temperature of $42{ }^{\circ} \mathrm{C}$ requires a drying time of 14 hours, with yield 22.00 $\%$, organoleptic value 7.88 Electric oven drying, the best treatment is drying with a temperature of $45^{\circ} \mathrm{C}(\mathrm{T} 2)$ Quality characteristics of the treatment T2 Drying using an electric oven temperature of $45{ }^{\circ} \mathrm{C}$ with organoleptic value 7.90 , yield $22.33 \%$, drying time 14.09 hours. Drying uses sunlight to produce a lawn with a brighter and less brittle appearance
\end{abstract}

Keywords: Organoleptic Quality, Drying, Pundang Seluang, and Temperature Variation 


\section{PENDAHULUAN}

Salah satu jenis ikan yang bernilai ekonomis tinggi yang banyak terdapat di perairan Sumatera Selatan adalah Ikan Seluang (Rasbora spp). Berdasarkan laporan Dinas Kelautan dan Perikanan Provinsi Sumatera Selatan Bidang Budidaya tahun 2015, pasokan ikan Seluang di Sumatera Selatan pada umumnya berasal dari tangkapan pada sungai utama maupun anak sungai Musi dan rawa-rawa yang tersebar luas di Sumatera Selatan Husnah dan Arsyad (2009).

Pengertian Pundang di daerah Kalimantan Tengah adalah penggaraman ikan atau daging yang dijemur dengan sinar matahari hingga keringnya merata (Rawit, 2009 dan Angking, 2009). Sedangkan pengertian Pundang di daerah Musi Banyuasin (Sumatera Selatan), Pundang adalah pengeringan ikan-ikan berukuran kecil (termasuk seluang) dengan sedikit penambahan garam sedangkan untuk penggaraman dan pengeringan ikan yang berukuran lebih besar disebut "Balur" (Ikan Asin) (Infokito (2007); Liuhartana dan Harris (2011) dan Dinas Kelautan dan Perikanan Provinsi Sumatera Selatan Bidang Bina Usaha, 2015). Mutu Pundang yang dihasilkan masyarakat saat ini masih beragam karena belum ada proses pengolahan yang baku antara satu pengolah Pundang dengan pengolah Pundang lainnya sehingga orang luar daerah Musi Banyuasin tidak banyak yang tahu kelebihan dan keunggulan Pundang ini (Haris dan Liuhartana, 2011; Harris dkk., 2011).

Menurut Adawiyah (2006), Ikan merupakan bahan pangan yang mudah rusak (membusuk) karena kandungan air yang tinggi (80 \%), $\mathrm{pH}$ tubuh ikan yang akan mendekati netral, daging ikan yang sangat mudah dicerna oleh enzim autolisis menyebabkan daging sangat lunak sehingga menjadi media yang baik untuk pertumbuhan bakteri pembusuk. Kandungan asam lemak tak jenuh mengakibatkan daging ikan mudah mengalami proses oksidasi sehingga menyebabkan bau tengik. Agar ikan Seluang dan hasil perikanan lainnya dapat dimanfaatkan semaksimal mungkin perlu dilakukan proses pengawetan, salah satunya dengan pengeringan. Kadar air yang mengalami penurunan akan mengakibatkan kandungan protein di dalam bahan mengalami peningkatan.

Pada umumnya pengeringan Pundang Seluang dilakukan dengan penjemuran di bawah sinar matahari. Tetapi permasalahannya adalah puncak musim ikan Seluang biasanya terjadi mada saat musim penghujan. Sehingga proses pengeringan menjadi titik kritis pada proses pengeringan Pundang ini. Sehingga ada pemikiran, bagaimana kalau pengeringan Pundang ini dilakukan dengan menggunakan oven elektrik, yang proses pengeringannya bisa dilakukan tanpa mengandalkan pada kondisi cuaca. Dengan menggunakan oven elektrik diharapkan proses pengeringan dapat dikendalikan, lebih higienis serta tidak tergantung pada cuaca sehingga mutu Pundang yang dihasilkan akan lebih baik. Penelitian ini bertujuan untuk : Mempelajari teknik pengeringan Pundang menggunakan oven elektrik, mengetahui karakteristik mutu organoleptik Pundang yang dikeringkan menggunakan oven elektrik.

\section{METODE PENELITIAN}

Bahan yang digunakan dalam pelaksanaan penelitian ini adalah sebagai berikut : Ikan Seluang segar (Rasbora $\mathrm{sp}$ ) dengan ukuran antara 9-12 cm dan jumlah per 100 gram adalah 18-20 ekor, garam beryodium, air. Alat yang digunakan dalam penelitian ini adalah sebagai berikut : Pisau, digunakan untuk membelah punggung Seluang menjadi bentuk Butterfly, timbangan digital, digunakan untuk menimbang Seluang, oven elektrik Sharp tipe EO-18L (W) 800 watt, digunakan untuk mengeringkan Seluang, peralatan pendukung lainnya untuk pengujian mutu Pundang.

\section{Uji Organoleptik (SNI 01-2346-2006)}

Pengujian organoleptik merupakan cara pengujian dengan indera manusia sebagai alat utama untuk pengukuran daya penerimaan terhadap makanan. Sasaran alat indera ditujukan terhadap kenampakan, bau, rasa, tekstur dan jamur. Metode pengujian dalam standar ini adalah uji skoring (scoring test), dengan menggunakan skala angka 1 (satu) sebagai nilai terendah dan angka 9 (sembilan) sebagai nilai tertinggi. Batas penolakan untuk produk ini adalah angka 5 (lima) artinya bila produk perikanan yang diuji memperoleh nilai yang sama atau kurang dari lima maka produk tersebut dinyatakan tidak lulus standar (SNI 01-2346-1991). Skala angka ini ditujukan dengan spesifikasi masingmasing produk yang dapat memberikan pengertian pada panelis. Skala angka dan spesifikasi ini dicantumkan dalam Score Sheet Organoleptik yang kemudian panelis langsung memberikan penilaian pada Score Sheet tersebut.

\section{Pengukuran Rendemen (AOAC, 2005)}

Rendemen merupakan hasil akhir yang dihitung berdasarkan proses input dan output.

Rendemen dihitung berdasarkan berat basah. Cara mengukur rendemen adalah sebagai berikut :

$$
\text { Rendemen }=\frac{A}{B} \times 100 \%
$$

Keterangan : $\mathrm{A}=$ berat akhir 


$$
\mathrm{B}=\text { berat awal }
$$

\section{Waktu Pengeringan}

Proses pengeringan Pundang menggunakan matahari dan oven elektrik dilakukan sampai kandungan air pada tubuh Pundang berkisar 10-12\%.

\section{Analisa Statistik}

Penelitian ini menggunakan Rancangan Acak Kelompok (RAK) dengan 4 (empat) taraf perlakuan, masing-masing perlakuan dilakukan 3 (tiga) kali ulangan. Perlakuan pada penelitian ini berupa penggunaan 4 (empat) variasi suhu yaitu : $\mathrm{T}_{0}$ (Pengeringan dengan sinar matahari), $\mathrm{T}_{1}$ (Pengeringan menggunakan oven elektrik suhu 40 ${ }^{0} \mathrm{C}$ ), $\mathrm{T}_{2}$ (Pengeringan menggunakan oven elektrik suhu $45{ }^{0} \mathrm{C}$ ), $\mathrm{T}_{3}$ (Pengeringan menggunakan oven elektrik suhu $50{ }^{\circ} \mathrm{C}$ ).

Denah penelitian adalah sebagai berikut:

\begin{tabular}{ccr}
\multicolumn{3}{c}{ BLOK } \\
\multicolumn{1}{c}{ KI } & KII & KIII \\
$\mathbf{T}_{\mathbf{0}}$ & $\mathbf{T}_{\mathbf{0}}$ & $\mathbf{T}_{\mathbf{0}}$ \\
$\mathbf{T}_{\mathbf{1}}$ & $\mathbf{T}_{\mathbf{1}}$ & $\mathbf{T}_{\mathbf{1}}$ \\
$\mathbf{T}_{\mathbf{2}}$ & $\mathbf{T}_{\mathbf{2}}$ & $\mathbf{T}_{\mathbf{2}}$ \\
$\mathbf{T}_{\mathbf{3}}$ & $\mathbf{T}_{\mathbf{3}}$ & $\mathbf{T}_{\mathbf{3}}$ \\
\multicolumn{2}{c}{ Gambar } & 1. Denah Penelitian
\end{tabular}

Penelitian ini menggunakan 2 (dua) tahap yaitu tahap pertama yang merupakan penelitian pendahuluan, untuk menentukan waktu pengeringan Pundang menggunakan matahari dan oven elektrik suhu $40{ }^{\circ} \mathrm{C}, 45^{\circ} \mathrm{C}$ dan $50{ }^{\circ} \mathrm{C}$. Tahap kedua yang merupakan penelitian utama yang bertujuan menentukan suhu pengeringan terbaik pada pengeringan Pundang menggunakan oven elektrik dan menentukan karakteristik mutu organoleptik dan mutu fisiknya.

Parameter yang diamati pada penelitian ini meliputi : analisa mutu organoleptik dan mutu fisik (rendemen, waktu pengeringan, warna dan tekstur). Data yang diperoleh diolah dengan menggunakan Analisa statistik parametrik, untuk data pengamatan uji organoleptik diolah menggunakan analisis keragaman (ANOVA) uji skoring taraf $5 \%$ dan $1 \%$ (Rahayu, 1994). Data yang diperoleh diolah dengan menggunakan Analisa statistik parametrik, untuk data pengamatan uji organoleptik, rendemen, waktu pengeringan, warna dan tekstur diolah menggunakan analisis keragaman (ANOVA) taraf $5 \%$ dan $1 \%$. Model matematika Rancangan Acak Kelompok (Gomez n Gomez 1995) adalah sebagai berikut :

Keterangan :

$$
\text { vij }=\mu+K j+\tau i+\varepsilon i j
$$

yij = Pengamatan perlakuan ke-i dan ulangan ke-j

$\mu \quad=$ Rataan umum populasi

$\mathrm{Kj}$ = Pengaruh dari kelompok ke-j $\tau \mathrm{i} \quad=$ Pengaruh perlakuan ke-i

$\varepsilon i j=$ Pengaruh dari sisa perlakuan ke-i dan ulangan ke-j

Data peubah yang diamati sebelum dilakukan Analisis Sidik Ragam atau Analysis Of Variance (ANOVA). Sebelum dilakukan pengolahan data menggunakan statistik parametrik dilakukan uji homogenitas. Uji homogenitas dilakukan untuk menentukan apakah sampel berasal dari varians yang homogen. Perhitungan homogenitas menggunakan Arsin, dengan rumus sebagai berikut :

Untuk mengetahui tingkat ketelitian digunakan uji Koefisien Keragaman (KK) dengan rumus sebagai berikut :

$$
K K(\%)=\frac{\sqrt{K T G}}{T} \times 100 \%
$$

Keterangan :

$K K \quad=$ Koefisien Keragaman.

$K T G \quad=$ Kuadrat Tengah Galat.

$T \quad=$ Rata-rata seluruh data percobaan

Pemilihan uji lanjut digunakan data berdasarkan hasil dari uji Koefisien Keragaman (KK). Menurut Gomez dan Gomez (1995) ada tiga kriteria yang dapat digunakan adalah :

Beda Nyata Terkecil (BNT)

Uji Beda Nyata Terkecil (BNT) digunakan

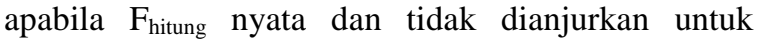
membandingkan semua pasang perlakuan yang mungkin, dengan Koefisien Keragaman (KK) $5 \%$.

Rumus Uji Beda Nyata Terkecil (BNT) adalah sebagai berikut :

$$
\mathrm{BNT} a=t(a, \mathrm{v}) \cdot \frac{\sqrt{2(\mathrm{KT} \mathrm{Galat})}}{\mathrm{r}}
$$

Keterangan :

$$
\begin{array}{ll}
\mathrm{t}(a, v) & =\text { Taraf nyata } a \text { dengan derajat bebas } v \\
(\text { KT Galat }) & =\text { Kuadrat Tengah Galat } \\
\mathrm{r} & =\text { Banyaknya Ulangan }
\end{array}
$$

\section{Uji Beda Nyata Jujur (BNJ)}

Uji Beda Nyata Jujur (BNJ) digunakan apabila $F_{\text {hitung nyata dan dapat digunakan untuk }}$ membandingkan semua pasang perlakuan yang ada, dengan Koefisien Keragaman (KK) 5-10 \%. Rumus Uji Lanjut Beda Nyata Jujur (BNJ) adalah sebagai berikut :

$$
\omega_{\alpha}=Q_{\alpha}(\mathrm{p}, \mathrm{v}) S_{y}
$$

Keterangan :

$$
\begin{array}{ll}
\omega_{\alpha} & =\text { Nilai BNJ pada taraf uji } \\
\mathrm{Q}_{\alpha} & =\text { Nilai baku Q pada taraf uji } \alpha . \\
\mathrm{P} & =\text { Jumlah perlakuan. } \\
\mathrm{V} & =\text { Derajat bebas galat. } \\
\mathrm{Sy} & =\text { Galat baku rerata umum. }
\end{array}
$$

\section{Uji Duncan}

Uji Duncan digunakan apabila $F_{\text {hitung nyata }}$ tetapi dapat digunakan untuk membandingkan semua 
pasang perlakuan yang ada, dengan Koefisien Keragaman (KK) $10 \%$. Rumus Uji Lanjut Duncan adalah sebagai berikut :

$$
\begin{aligned}
& \text { Duncan }=\mathrm{t} \alpha / 2 ; \mathrm{dbs} \frac{\sqrt{2 K T S}}{r} \\
& \text { Keterangan : } \\
& \text { KTS = Kuadrat Tengah Sisa } \\
& \text { Dbs = Derajat Bebas Sisa } \\
& \mathrm{r}=\text { Banyaknya Ulangan }
\end{aligned}
$$

\section{HASIL DAN PEMBAHASAN}

\section{A. Uji Organoleptik (SNI 01-2346-2006)}

Pengujian organoleptik merupakan cara pengujian dengan indera manusia sebagai alat utama untuk pengukuran daya penerimaan terhadap makanan. Sasaran alat indera ditujukan terhadap kenampakan, bau, rasa, tekstur dan jamur.

\section{Kenampakan}

Nilai rata-rata skor organoleptik kenampakan Pundang dapat dilihat pada Gambar 2.

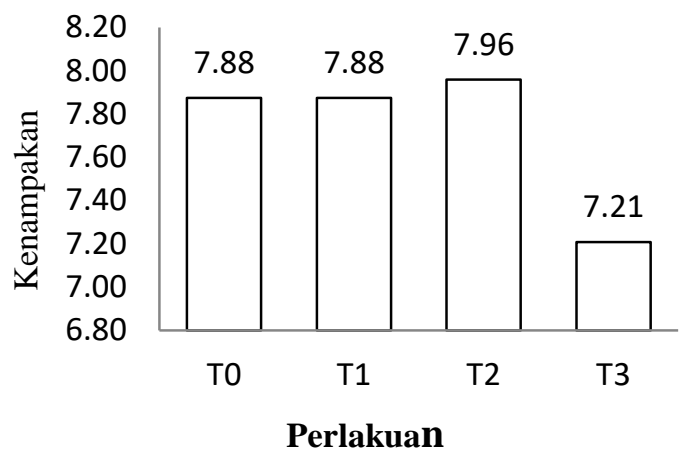

Gambar 2. Rerata Skor Organoleptik Kenampakan Pundang.

Nilai rata-rata organoleptik kenampakan Pundang menunjukkan skor tertinggi terdapat pada perlakuan $\mathrm{T}_{2}$ (pengeringan menggunakan oven elektrik suhu $45{ }^{\circ} \mathrm{C}$ ) dengan nilai rata - rata 7,96 , sedangkan nilai rata-rata uji organoleptik terendah terdapat pada perlakuan $\mathrm{T}_{3}$ (pengeringan menggunakan oven elektrik suhu $50{ }^{\circ} \mathrm{C}$ ) dengan nilai rata-rata 7,21. Hasil analisis keragaman menunjukan bahwa perlakuan pengeringan Pundang berbeda sangat nyata terhadap sifat organoleptik kenampakan yang dihasilkan dengan Koefisien Keragaman (KK) $=0,04 \%$. Nilai KK kurang dari $5 \%$ maka untuk uji lanjut digunakan uji BNT.

Hasil uji lanjut BNT menunjukkan bahwa perlakuan $T_{2}$ (pengeringan menggunakan oven elektrik suhu $45{ }^{\circ} \mathrm{C}$ ), $\mathrm{T}_{0}$ (pengeringan dengan sinar matahari) dan $T_{1}$ (pengeringan menggunakan oven elektrik suhu $40{ }^{\circ} \mathrm{C}$ ) berbeda tidak nyata, sedangkan perlakuan $\mathrm{T}_{3}$ (pengeringan menggunakan oven elektrik suhu $50{ }^{\circ} \mathrm{C}$ ) berbeda nyata dengan perlakuan $\mathrm{T}_{2}$ (pengeringan menggunakan oven elektrik suhu 45 ${ }^{0} \mathrm{C}$ ), $\mathrm{T}_{0}$ (pengeringan dengan sinar matahari) dan $\mathrm{T}_{1}$ (pengeringan menggunakan oven elektrik suhu 40 ${ }^{0} \mathrm{C}$ ). Nilai rata-rata organoleptik Pundang adalah 7,20 - 7,96 dengan kenampakan Pundang yang dihasilkan utuh, bersih, kurang rapi, bercahaya menurut jenis. Standar organoleptik Pundang mengacu pada standar ikan asin kering SNI 2721.1:2009 (BSN, 2009) dengan nilai standarnya 7 dari semua perlakuan telah memenuhi standar mutu ikan asin kering 2721.1:2009 (BSN, 2009). Kenampakan Pundang yang mengkilap atau bercaya menurut jenis dipengaruhi oleh suhu panas yang digunakan selama pengeringan. Pengaruh panas selama pengeringan dapat menyebabkan terjadinya reaksi pencoklatan (Maillard) antara senyawa amino dengan gula pereduksi. Gula pereduksi pada ikan merupakan hasil pemecahan glikogen sesaat setelah ikan mati. Reaksi antara asam amino dengan gula pereduksi akan membentuk melanoidin, suatu polimer berwarna coklat yang dapat menurunkan nilai kenampakan produk. Pencoklatan juga terjadi karena reaksi antara protein, peptida dan asam amino dengan hasil dekomposisi lemak (Lee, 1983) dalam (Sedjati, 2006). Semakin tinggi suhu yang digunakan maka Pundang yang dihasilkan semakin coklat dan semakin mengkilap (Fadly, 2013).

\section{Bau}

Pengujian organoleptik bau adalah cara pengujian dengan indera manusia sebagai alat utama untuk pengukuran daya penerimaan terhadap makanan. Nilai rata-rata skor organoleptik bau Pundang dapat dilihat pada Gambar 3.

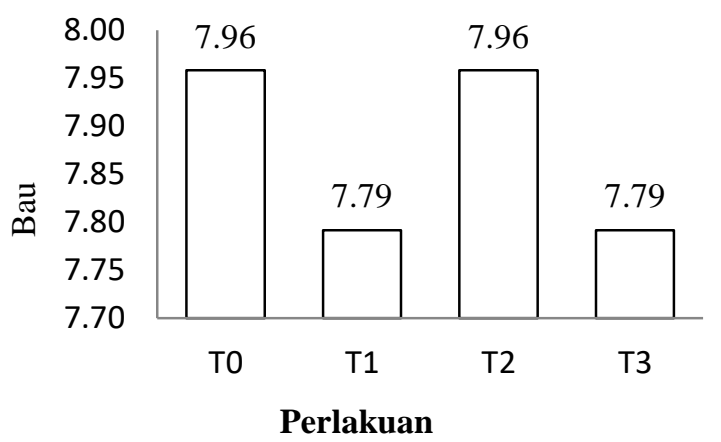

Gambar 3. Rerata Skor Organoleptik Bau Pundang.

Nilai rata-rata organoleptik bau Pundang menunjukkan skor tertinggi terdapat pada perlakuan $\mathrm{T}_{0}$ (pengeringan dengan sinar matahari) dan $\mathrm{T}_{2}$ (pengeringan menggunakan oven elektrik suhu $45^{\circ} \mathrm{C}$ ) dengan nilai rata - rata 7,96, sedangkan nilai rata-rata organoleptik bau terendah terdapat pada perlakuan $\mathrm{T}_{1}$ (pengeringan menggunakan oven elektrik suhu $40{ }^{\circ} \mathrm{C}$ ) dan $T_{3}$ (pengeringan menggunakan oven elektrik 
suhu $50{ }^{\circ} \mathrm{C}$ ) dengan nilai rata-rata 7,79. Hasil analisis keragaman menunjukan bahwa perlakuan pengeringan Pundang berbeda tidak nyata terhadap sifat organoleptik bau yang dihasilkan dengan Koefisien Keragaman $(\mathrm{KK})=0,04 \%$.

\section{Rasa}

Pengujian organoleptik rasa adalah cara pengujian dengan indera manusia sebagai alat utama untuk pengukuran daya penerimaan terhadap makanan. Nilai rata-rata skor organoleptik rasa Pundang dapat dilihat pada Gambar 4.

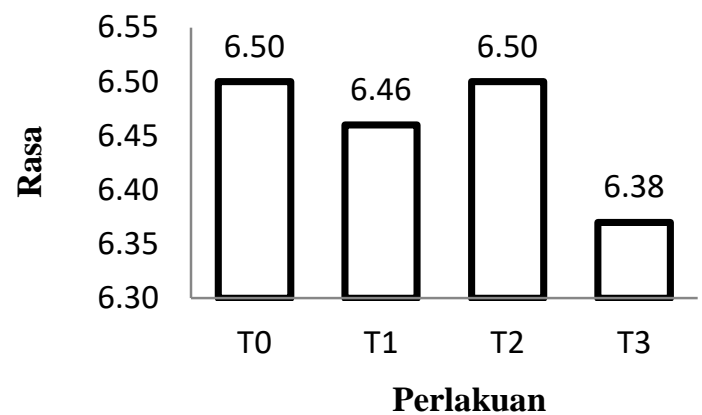

Gambar 4. Rerata Skor Organoleptik Rasa Pundang. Nilai rata-rata organoleptik rasa Pundang menunjukkan skor tertinggi terdapat pada perlakuan $\mathrm{T}_{0}$ (pengeringan dengan sinar matahari) dan $\mathrm{T}_{2}$ (pengeringan menggunakan oven elektrik suhu $45{ }^{\circ} \mathrm{C}$ ) dengan nilai rata - rata 6,50 , sedangkan nilai rata-rata organoleptik rasa terendah terdapat pada $T_{3}$ (pengeringan menggunakan oven elektrik suhu $50{ }^{\circ} \mathrm{C}$ ) dengan nilai rata-rata 6,38 . Hasil analisis keragaman menunjukan bahwa perlakuan pengeringan Pundang berbeda tidak nyata terhadap sifat organoleptik rasa yang dihasilkan dengan Koefisien Keragaman (KK) $=0,03 \%$.

\section{Tekstur}

Tekstur suatu bahan erat kaitannya dengan kandungan air yang ada dalam bahan pangan tersebut. Semakin kecil kandungan airnya maka bahan pangan tersebut akan semakin rapuh (Winarno, 2002). Nilai rata-rata skor organoleptik tekstur Pundang dapat dilihat pada Gambar 5.

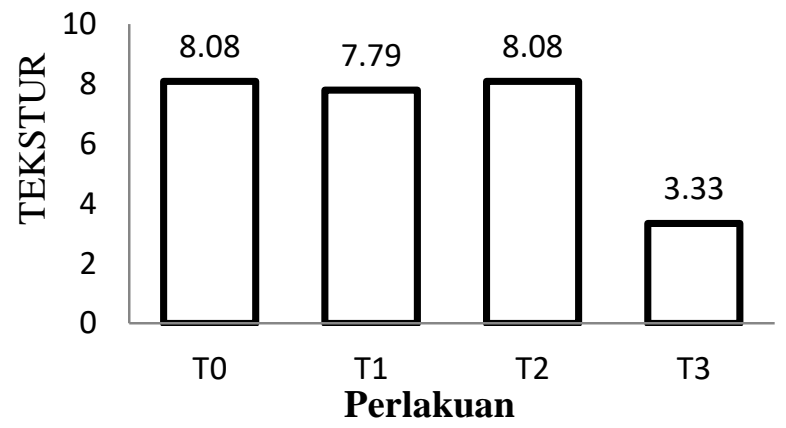

Gambar 5. Rerata Skor Organoleptik Tekstur Pundang.
Nilai rata-rata tekstur menunjukkan nilai tertinggi terdapat pada perlakuan $\mathrm{T}_{0}$ (pengeringan dengan sinar matahari) dan $\mathrm{T}_{2}$ (pengeringan menggunakan oven elektrik suhu $45^{\circ} \mathrm{C}$ ) dengan nilai rata-rata 8,08 sedangkan nilai rata-rata tekstur terendah terdapat pada perlakuan $\mathrm{T}_{3}$ (pengeringan menggunakan oven elektrik suhu $50{ }^{\circ} \mathrm{C}$ ) dengan nilai rata-rata 3,33. Hasil analisis koefisien keragaman menunjukan bahwa perlakuan pengeringan Pundang berbeda sangat nyata terhadap nilai organoleptik tekstur yang dihasilkan dengan $\mathrm{KK}=0,13 \%$, karena nilai KK kurang dari $5 \%$ maka dilakukan uji lanjut BNT. Hasil uji lanjut BNT

Hasil uji lanjut BNT menunjukkan bahwa perlakuan $\mathrm{T}_{0}$ (pengeringan dengan sinar matahari), $\mathrm{T}_{2}$ (pengeringan menggunakan oven elektrik suhu $45^{\circ} \mathrm{C}$ ) dan $\mathrm{T}_{1}$ (pengeringan menggunakan oven elektrik suhu $40{ }^{0} \mathrm{C}$ ) berbeda tidak nyata, sedangkan perlakuan $\mathrm{T}_{3}$ (pengeringan menggunakan oven elektrik suhu $50{ }^{\circ} \mathrm{C}$ ) berbeda nyata dengan perlakuan $\mathrm{T}_{0}$ (pengeringan dengan sinar matahari), $\mathrm{T}_{2}$ (pengeringan menggunakan oven elektrik suhu $45{ }^{\circ} \mathrm{C}$ ) dan $\mathrm{T}_{1}$ (pengeringan menggunakan oven elektrik suhu $40{ }^{\circ} \mathrm{C}$ ). Dari semua kombinasi perlakuan, memperoleh nilai rata-rata organoleptik tekstur 3,33 - 8,08 dengan tekstur Pundang yang dihasilkan padat, kompak, lentur dan kurang kering untuk perlakuan $\mathrm{T}_{0}$ (pengeringan dengan sinar matahari), $\mathrm{T}_{1}$ (pengeringan menggunakan oven elektrik suhu $40{ }^{\circ} \mathrm{C}$ ) dan $\mathrm{T}_{2}$ (pengeringan menggunakan oven elektrik suhu $45{ }^{\circ} \mathrm{C}$ ), sedangkan perlakuan $\mathrm{T}_{3}$ (pengeringan menggunakan oven elektrik suhu $50{ }^{\circ} \mathrm{C}$ ) tekstur Pundang yang dihasilkan kering, rapuh dan mudah terurai, hal ini disebabkan oleh semakin tingginya suhu yang digunakan dalam proses pengeringan Pundang. Suparno (1992) menyatakan bahwa pengeringan yang dilakukan pada suhu yang terlalu tinggi dapat menyebabkan terjadinya case hardening yaitu proses pengeringan yang menyebabkan permukaan mengering lebih cepat dibandingkan bagian dalamnya oleh karena itu harus diusahakan agar suhu pengeringan selama proses tidak terlalu tinggi (tidak melebihi $45{ }^{\circ} \mathrm{C}$ ).

\section{Jamur}

Pundang hasil penelitian ini pada semua kombinasi perlakuan tidak ditemukan adanya pertumbuhan kapang atau jamur sehingga dapat memenuhi standar ikan asin kering SNI 2721.1:2009 (BSN, 2009) hal ini disebabkan karena kadar air Pundang cukup rendah berkisar $8 \%$ jadi kecil kemungkinan kapang dapat tumbuh. Moeljanto (1982) menyatakan bahwa batas kadar air yang diperlukan agar pertumbuhan kapang dapat terhambat berkisar $30-40 \%$. 


\section{Skor Keseluruhan Uji Organoleptik}

Nilai rata-rata skor keseluruhan uji organoleptik Pundang dapat dilihat pada Gambar 6.

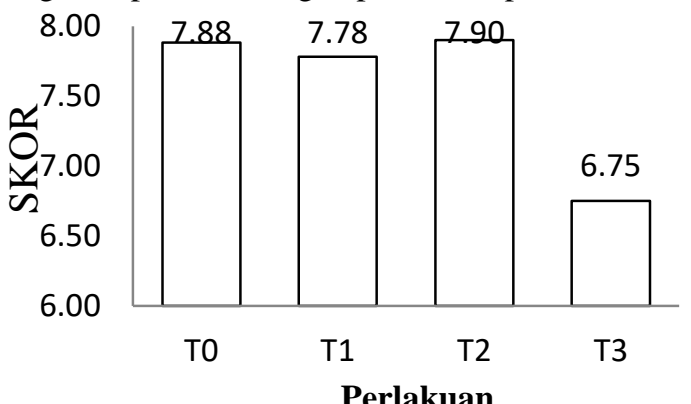

Gambar 6. Rata-rata skor uji organoleptik Pundang.

Rata-rata uji organoleptik menunjukkan skor tertinggi terdapat pada perlakuan $\mathrm{T}_{2}$ (pengeringan menggunakan oven elektrik suhu $45{ }^{\circ} \mathrm{C}$ ) dengan nilai rata - rata 7.90, sedangkan nilai rata-rata uji organoleptik terendah terdapat pada perlakuan $\mathrm{T}_{3}$ (pengeringan menggunakan oven elektrik suhu $50{ }^{\circ} \mathrm{C}$ ) dengan nilai rata-rata 6,75 . Hasil analisis keragaman menunjukan bahwa perlakuan pengeringan Pundang berbeda sangat nyata terhadap sifat organoleptik yang dihasilkan dengan Koefisien Keragaman $(\mathrm{KK})=0,03$ $\%$. Nilai KK kurang dari 5\% maka untuk uji lanjut digunakan uji BNT.

Hasil uji lanjut BNT menunjukkan bahwa perlakuan $\mathrm{T}_{2}$ (pengeringan menggunakan oven elektrik suhu $45{ }^{\circ} \mathrm{C}$ ), $\mathrm{T}_{0}$ (pengeringan dengan sinar matahari) dan $T_{1}$ (pengeringan menggunakan oven elektrik suhu $40{ }^{\circ} \mathrm{C}$ ) berbeda tidak nyata, sedangkan perlakuan $\mathrm{T}_{3}$ (pengeringan menggunakan oven elektrik suhu $50{ }^{\circ} \mathrm{C}$ ) berbeda nyata dengan perlakuan $\mathrm{T}_{2}$ (pengeringan menggunakan oven elektrik suhu 45 ${ }^{0} \mathrm{C}$ ), $\mathrm{T}_{0}$ (pengeringan dengan sinar matahari) dan $\mathrm{T}_{1}$ (pengeringan menggunakan oven elektrik suhu 40 $\left.{ }^{0} \mathrm{C}\right)$. Tinggi rendahnya nilai organoleptik dipengaruhi oleh tolak nilai dari kenampakan, bau, rasa, tekstur dan ada tidaknya jamur pada Pundang itu sendiri. Pengujian organoleptik Pundang menggunakan skala angka 1 (satu) sebagai nilai terendah dan angka 9 (sembilan) sebagai nilai tertinggi.

Batas penolakan untuk produk ini adalah angka 5 (lima) artinya bila produk perikanan yang diuji memperoleh nilai yang sama atau kurang dari lima maka produk tersebut dinyatakan tidak lulus standar SNI 01-2346-1991 (BSN, 1991). Berdasarkan Gambar 10 diketahui bahwa rata-rata skor organoleptik Pundang baik perlakuan $T_{0}$ (pengeringan dengan sinar matahari), $\mathrm{T}_{1}$ (pengeringan menggunakan oven elektrik suhu $40{ }^{\circ} \mathrm{C}$ ) dan $\mathrm{T}_{2}$ (pengeringan menggunakan oven elektrik suhu $45{ }^{\circ} \mathrm{C}$ ) standar mutu ikan asin kering SNI 2721. 1 : 2009 (BSN, 2009) dengan nilai standarnya 7, sedangkan pada perlakuan $\mathrm{T}_{3}$ masih belum memenuhi syarat standar mutu ikan asin kering dengan nilai rata-rata 6.75 dengan kenampakan Pundang yang agak kusam. Kenampakan yang agak kusam disebabkan suhu yang digunakan pada perlakuan $T_{3}$ (pengeringan menggunakan oven elektrik suhu 50 $\left.{ }^{0} \mathrm{C}\right)$. Hal ini menunjukkan bahwa pengeringan Pundang dengan suhu $40-45{ }^{\circ} \mathrm{C}$ masih memenuhi mutu organoleptik yang baik, tetapi suhu lebih dari $45{ }^{0} \mathrm{C}$ mutu Pundang yang dihasilkan sudah mengalami kerusakan fisik dan kimia yang menyebabkan warna Pundang yang dihasilkan menjadi kusam (Suparno, 1992).

\section{B. Analisa Fisik \\ 1. Rendemen}

Rendemen merupakan hasil akhir yang dihitung berdasarkan proses input dan output. Adapun hasil nilai rata-rata rendemen Pundang dapat dilihat pada Gambar 7.

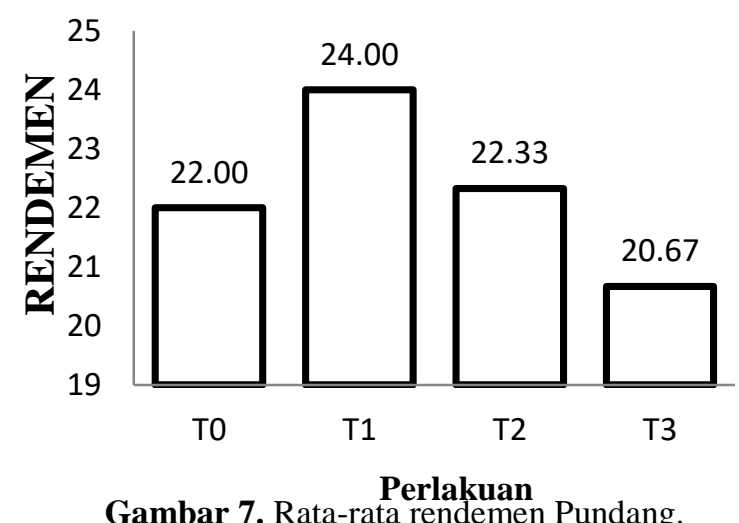

Nilai rata-rata rendemen menunjukkan nilai tertinggi terdapat pada perlakuan $\mathrm{T}_{1}$ (pengeringan menggunakan oven elektrik suhu $40{ }^{\circ} \mathrm{C}$ ) dengan nilai rata-rata $24,00 \%$, sedangkan nilai rata-rata rendemen terendah terdapat pada perlakuan $\mathrm{T}_{3}$ (pengeringan menggunakan oven elektrik suhu $50{ }^{\circ} \mathrm{C}$ ) dengan nilai rata-rata 20,67\%. Hasil analisis keragaman menunjukan bahwa perlakuan pengeringan Pundang berbeda sangat nyata terhadap nilai rendemen yang dihasilkan, dengan $\mathrm{KK}=2,48 \%$, karena KK kurang dari $5 \%$ maka dilakukan uji lanjut BNT.

Hasil uji lanjut BNT menunjukkan bahwa perlakuan $\mathrm{T}_{1}$ (pengeringan menggunakan oven elektrik suhu $40{ }^{0} \mathrm{C}$ ) dan $\mathrm{T}_{2}$ (pengeringan menggunakan oven elektrik suhu $45{ }^{\circ} \mathrm{C}$ ) berbeda tidak nyata, begitu juga dengan perlakuan $T_{2}$ (pengeringan menggunakan oven elektrik suhu 45 ${ }^{0} \mathrm{C}$ ), $\mathrm{T}_{0}$ (pengeringan dengan sinar matahari) dan $\mathrm{T}_{3}$ (pengeringan menggunakan oven elektrik suhu $50{ }^{\circ} \mathrm{C}$ ) berbeda tidak nyata, tetapi perlakuan $\mathrm{T}_{1}$ (pengeringan menggunakan oven elektrik suhu $40{ }^{\circ} \mathrm{C}$ ) berbeda 
nyata dengan perlakuan $\mathrm{T}_{0}$ (pengeringan dengan sinar matahari) dan $\mathrm{T}_{3}$ (pengeringan menggunakan oven elektrik suhu $\left.50{ }^{0} \mathrm{C}\right)$. Nilai rata-rata rendemen Pundang cenderung mengalami penurunan hal ini disebabkan oleh semakin tingginya suhu yang digunakan dalam proses pengeringan Pundang. Semakin tinggi suhu udara semakin besar energi panas yang dibawa udara, maka semakin banyak jumlah massa cairan yang diuapkan dari permukaan bahan yang dikeringkan (Adawyah, 2006).

\section{Waktu Pengeringan}

Waktu pengeringan Pundang menggunakan matahari dan oven elektrik dilakukan sampai kandungan air pada Pundang berkisar 10-12\%. Adapun hasil nilai rata-rata waktu pengeringan Pundang dapat dilihat pada Gambar 8.

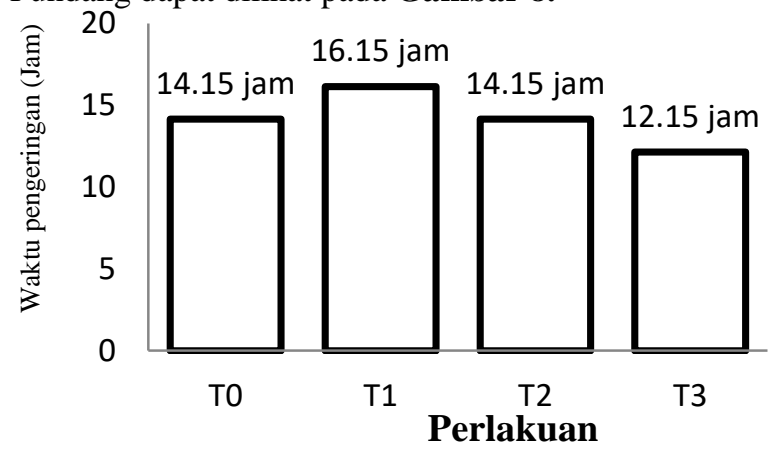

Gambar 8. Rata-rata waktu pengeringan Pundang.

Nilai rata-rata waktu pengeringan menunjukkan nilai dari yang tertinggi ke yang terendah adalah perlakuan $T_{1}$ (pengeringan menggunakan oven elektrik suhu $40{ }^{\circ} \mathrm{C}$ ) dengan nilai rata-rata 16,15 jam, perlakuan $T_{0}$ (Pengeringan dengan sinar matahari) dengan nilai rata-rata 14,15 jam, $\mathrm{T}_{2}$ (pengeringan menggunakan oven elektrik suhu $45{ }^{\circ} \mathrm{C}$ ) dengan nilai rata-rata 14,15 jam dan perlakuan $\mathrm{T}_{3}$ (pengeringan menggunakan oven elektrik suhu $50{ }^{\circ} \mathrm{C}$ ) dengan nilai rata-rata 12,15 jam. Hasil analisis keragaman menunjukan bahwa perlakuan pengeringan Pundang berbeda sangat nyata terhadap waktu pengeringan yang dibutuhkan dengan nilai $\mathrm{KK}=0,12 \%$, karena nilai KK kurang dari $5 \%$ maka dilakukan uji lanjut BNT.

Hasil uji lanjut BNT menunjukkan bahwa perlakuan $\mathrm{T}_{1}$ (pengeringan menggunakan oven elektrik suhu $40{ }^{\circ} \mathrm{C}$ ) berbeda nyata dengan perlakuan $\mathrm{T}_{0}$ (pengeringan dengan sinar matahari) sedangkan $\mathrm{T}_{0}$ (pengeringan dengan sinar matahari) berbeda tidak nyata dengan perlakuan $\mathrm{T}_{2}$ (pengeringan menggunakan oven elektrik suhu $45{ }^{\circ} \mathrm{C}$ ) dan perlakuan $\mathrm{T}_{2}$ (pengeringan menggunakan oven elektrik suhu $45^{\circ} \mathrm{C}$ ) berbeda nyata dengan perlakuan $\mathrm{T}_{3}$ (pengeringan menggunakan oven elektrik suhu 50 $\left.{ }^{0} \mathrm{C}\right)$. Nilai rata-rata waktu pengeringan cenderung lebih cepat dengan semakin tingginya suhu yang digunakan dalam proses pengeringan Pundang. Estiasih dan Ahmadi (2009) menyatakan bahwa faktor yang mempengaruhi kecepatan proses pengeringan ikan salah satunya adalah suhu pengeringan. Adawyah (2006) menyatakan bahwa suhu yang semakin tinggi mengakibatkan proses pengeringan berlangsung lebih cepat. Semakin tinggi suhu udara semakin besar energi panas yang dibawa udara, sehingga semakin banyak jumlah massa cairan yang diuapkan dari permukaan bahan yang dikeringkan.

\section{KESIMPULAN DAN SARAN}

\section{A. Kesimpulan}

Berdasarkan hasil penelitian yang diperoleh maka dapat disimpulkan sebagai berikut :

1. Suhu pengeringan yang terbaik menggunakan sinar matahari dengan suhu rata-rata $42{ }^{\circ} \mathrm{C}$, sedangkan. Suhu pengeringan yang terbaik untuk pengeringan Pundang menggunakan oven elektrik adalah suhu $45^{\circ} \mathrm{C}$.

2. Karakteristik mutu Pundang dari perlakuan terbaik pengeringan menggunakan oven elektrik adalah $\mathrm{T}_{2}$ Pengeringan menggunakan oven elektrik suhu $45{ }^{\circ} \mathrm{C}$ dan $\mathrm{T}_{0}$ Pengeringan dengan sinar matahari (kontrol) dengan nilai organoleptik $\mathrm{T}_{0}(7.88), \mathrm{T}_{2}(7.90)$, rendemen $\mathrm{T}_{0}(22.00 \%), \mathrm{T}_{2}$ $(22.33 \%)$, waktu pengeringan $\mathrm{T}_{0}(14.15 \mathrm{jam}), \mathrm{T}_{2}$ (14.15 jam).

3. Pengeringan menggunakan sinar matahari menghasilkan pundang dengan penampakan lebih cerah dan tidak getas, sedangkan pengeringan dengan oven elektrik menghasilkan Pundang kurang cerah dan lebih getas.

B. Saran

1. Pengeringan Pundang menggunakan oven elektrik sebaiknya pada suhu $45^{\circ} \mathrm{C}$ selama 14.15 jam.

2. Untuk mendapatkan informasi yang lebih mendalam tentang nilai gizi Pundang Seluang, maka perlu dilakukan penelitian lebih lanjut tentang mutu kimia dan mikrobiologi Pundang Seluang.

\section{UCAPAN TERIMA KASIH}

Penelitian ini adalah bagian dari kegiatan "Perbaikan Teknologi Proses Pengolahan Untuk Meningkatkan Mutu Seluang Kering (Pundang) Sebagai Produk Unggulan Khas Sumatera Selatan” yang didanai oleh Hibah Penenelitian DRPM Dikti Skim Hibah Bersaing tahun 2017 dan 2018 dengan ketua peneliti Dr.Ir. Helmi Haris, MS. Artikel ini dipresentasikan pada Seminar Hasil Penelitian dan 
Pengabdian Masyarakat Yang Telah Dilaksanakan tanggal 25 Nopember 2017 di Palembang, Indonesia.

\section{DAFTAR PUSTAKA}

Adawyah, R. 2006. Pengolahan dan Pengawetran Ikan. Bumi Aksara. Jakarta.

Angking. 2009. Pundang Ikan Asin. (Online)(http://angking.wordpress.com). Diakses tanggal 2 Oktober 2017.

AOAC. 2005. Methods of analysis. Association of Official Agricultural Chemist. Washington DC.

Badan Standardisasi Nasional. 2006. Petunjuk Pengujian Organoleptik dan Sensori. SNI 012346-2006. BSN. Jakarta.

Badan Standardisasi Nasional. 2009. Standar Nasional Indonesia (SNI) Ikan Asin. SNI 2721.1:2009. BSN. Jakarta.

Dinas Kelautan dan Perikanan Provinsi Sumatera Selatan. 2015. Statistik Perikanan. Dinas Kelautan dan Perikanan Provinsi Sumatera Selatan Bidang Budidaya Perikanan Provinsi Sumatera Selatan. Palembang.

Dinas Kelautan dan Perikanan Provinsi Sumatera Selatan. 2015. Statistik Perikanan. Dinas Kelautan dan Perikanan Provinsi Sumatera Selatan Bidang Bina Usaha Perikanan Provinsi Sumatera Selatan. Palembang.

Estiasih, T. dan K. Ahmadi. 2009. Teknologi Pengolahan Pangan. Bumi Aksara. Jakarta.

Fadly. M. 2013. Penentuan Umur Simpan (Shelf Life) Pundang Seluang (Rasbora $\mathrm{sp}$ ) yang Dikemas Menggunakan Kemasan Vakum dan Tanpa Vakum. Skripsi. Fakultas Perikanan Universitas PGRI Palembang.

Gomez, K.A. dan AA. Gomez. 1995. Prosedur Statistik Untuk Penelitian Pertanian (Endang Syamsudin dan Justika S. Baharsyah). Universitas Indonesia (UI-Press). Jakarta.

Harris, H. dan R. Liuhartana. 2011. Disain Kemasan Untuk Meningkatkan Fungsi dan Tampilan Seluang Kering (Pundang). Jurnal Ilmu-Ilmu Perikanan dan Budidaya Perairan 6
(1) : 27-40. Fakultas Perikanan Universitas PGRI Palembang. Palembang.

Harris, H., R. Liuhartana, F. Muliajaya dan E. Robiyardi. 2014. Perbaikan Teknologi Proses Pengolahan Untuk Meningkatkan Mutu Seluang Kering (Pundang) Sebagai Produk Unggulan Khas Sumatera Selatan. Fakultas Perikanan Universitas PGRI Palembang. Palembang.

Liuhartana, R. dan H.Harris. 2011. Identifikasi Proses Pengolahan dan Analisa Mutu Seluang Kering (Pundang) pada Pengolahan Secara Tradisional. Jurnal Ilmu-Ilmu Perikanan dan Budidaya Perairan 6 (1) : 41-54. Fakultas Perikanan Universitas PGRI Palembang. Palembang.

Husnah dan M. N. Arsyad. 2009. Keragaman Jenis, Sebaran, Habitat dan Karakteristik Biologi Ikan Seluang (Rasbora sp) di Perairan Umum. Universitas PGRI Palembang Kerjasama dengan Balai Riset Perikanan Perairan Umum. Palembang.

Infokito. 2007. Produk Industri Muba Dipatenkan. (Online) (http://infokito.wordpress.com). Diakses tanggal 2 Oktober 2017.

Moeljanto. 1982. Penggaraman dan Pengeringan Ikan. Penebar Swadaya. Jakarta

Rahayu, W. N. 1994. Penuntun Praktikum Penilaian Organoleptik. Jurusan Teknologi Pangan dan Gizi. Fakultas Teknologi Pertanian. IPB.

Rawit, N. 2009. Maneser Panatau Tatu Hiang. (Online) (http://maneser.kalteng.net). Diakses tanggal 2 Oktober 2017.

Sedjati, S. 2006. Pengaruh Konsentrasi Khitosan Terhadap Mutu Ikan Teri (Stolephorus heterolobus) Asin Kering Selama Penyimpanan Suhu Kamar. Tesis. Program Pasca Sarjana. Universitas Diponegoro Semarang.

Suparno. 1992. Pengeringan Ikan dalam Kumpulan Hasil Penelitian Pasca Panen Perikanan. Balai Penelitian Teknologi Perikanan. Jakarta.

Winarno, F. G. 2002. Kimia Pangan dan Gizi. Gramedia. Jakarta. 